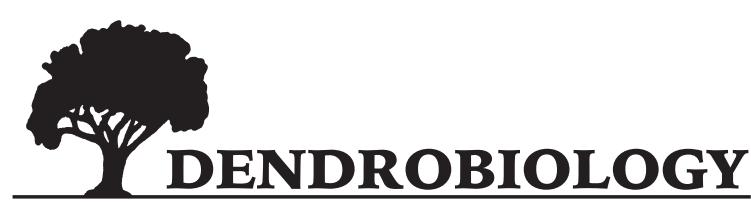

2018, vol. 79, 10-19

http://dx.doi.org/10.12657/denbio.079.002

\author{
Mariana Kýpetová, Łukasz Walas, Peter Jaloviar, Grzegorz Iszkuło
}

\section{Influence of herbivory pressure on the growth rate and needle morphology of Taxus baccata $\mathrm{L}$. juveniles}

Received: 14 June 2017; Accepted: 4 October 2017

\begin{abstract}
Damage by herbivore grazing negatively influences the development of subsequent forest generations. Little is known about the long-term impacts of grazing and interactions between grazing and light conditions on sapling growth after the cessation of herbivory impact. In this study, Taxus baccata saplings were grown over a period of four years in artificial shading at 2, 8, 30 and 100\% of full sunlight (described as initial light). These saplings were planted in fenced and unfenced plots in a mixed forest in Poland. After six years with no protection from grazing, deer pressure was eliminated by fencing. In this study, we analysed sapling growth and needle morphology five years after deer suppression. Overall, grazing had a negative significant impact on the growth rate and needle morphology of $T$. baccata saplings. Saplings damaged by herbivores had a height increment approximately one-third that of non-grazed saplings. The grazed yew saplings had a lower needle area and length and a higher specific leaf area (SLA) than non-grazed saplings. Initial and current light conditions did not influence tree growth rates and needle morphology. However, we found positive correlations between sapling height and both leaf area and leaf length and a negative correlation between sapling height and SLA. Browsed yews also had a greater tendency to form polycormic (multi-stemmed) individuals. Lower growth rates, smaller needles and polycormic stems indicate a strategy of "escaping" herbivory pressure even five years after elimination of deer pressure.
\end{abstract}

Keywords: Taxus baccata L., herbivory grazing, regeneration, sapling growth

Addresses: M. Kýpetová, Faculty of Forestry, Technical University, 96053 Zvolen, Slovakia, e-mail: mariana.kypetova@tuzvo.sk

Ł. Walas, Institute of Dendrology, Polish Academy of Sciences, 62-035 Kórnik, Poland, e-mail: lukaswalas@wp.pl

P. Jaloviar, Faculty of Forestry, Technical University, 96053 Zvolen, Slovakia,

e-mail: peter.jaloviar@tuzvo.sk

G. Iszkuło, Institute of Dendrology, Polish Academy of Sciences, 62-035 Kórnik, Poland and Faculty of Biological Science, University of Zielona Gora, 65-516 Zielona Gora, Poland,

e-mail: iszkulo@man.poznan.pl 


\section{Introduction}

Browsing by herbivores is one of the most limiting factors of natural and artificial regeneration in central European forests (Kamler et al., 2010). Wild ungulates are a natural part of forest ecosystems, and young trees are a normal part of their diet (Kupferschmid et al., 2013). However, browsing by mammalian herbivores can cause considerable damage to woody plants of ecological and silvicultural significance (Duncan et al., 1998). Therefore, many studies have evaluated the effect of grazing on the growth of various tree species (e.g. Kupferschmid et al., 2013; Tanentzap et al., 2012; Heuze et al., 2005; Vila et al., 2003). Deer browsing and bark stripping markedly limit normal tree growth and development in three main ways: browsing on seedlings, browsing on terminal shoots or browsing on lateral shoots. According to this, we can distinguish the structural changes of trees in terms of wood density, height growth or foliage density (Gill \& Beardall, 2001). During the early stages of forest regeneration, foresters deal with the issue of deer browsing to ensure the protection and regeneration of target tree species. Hereby, they have to choose appropriate methods to reduce herbivore damage, e.g. mechanical or chemical protection (Kamler et al., 2010). The damage caused by deer browsing can be severe and markedly influence the survival and growth of endangered species. Taxus baccata $\mathrm{L}$. is one of these endangered rare species and is currently conserved by different regimes of protection (Thomas \& Polwart, 2003; Schirone et al., 2010; Vessella et al., 2013; Vessella et al., 2015). Therefore, certain woodland communities containing Taxus baccata have received priority habitat status (EU Habitat Directive 92/43/EEC), but climatic changes may further enhance the decline of this species (Garbarino et al., 2015; Thomas \& Garcia-Marti, 2015; Vessella et al., 2015). Because of these threats, a number of yew conservation and restoration programs have been launched in many European regions (Farris et al., 2012; Katsavou \& Ganatsas, 2012; Peragón et al., 2015), including Poland (Niemczyk et al., 2015). The result of these projects is the enrichment of tree species composition of Polish state forests with planted yew and the realisation of active management with a partial conservation regime in order to maintain this valuable tree species (Magnuszewski, 2015). Despite the high toxicity of plant organs of Taxus, the species is highly browsed by deer (Svenning \& Magård, 1999; García et al., 2000; Mysterud \& Østbye, 2004; Perrin et al., 2006).

So far, the studies regarding the influence of deer pressure focused primarily on the survival of tree regeneration (e.g., Mysterud \& Østbye, 2004; Farris \& Filigheddu, 2008) and the changes in tree species composition resulting from animals grazing preferences (Augustine \& McNaughton, 1998; Gill
\& Beardall, 2001). However, few studies have considered the effects on the growth and physiology of seedlings and saplings after the elimination of herbivore pressure. Cessation of herbivore pressure may occur as a consequence of fencing, or after the regeneration has outgrown the reach of ungulates and became unavailable for herbivory (Zamora et al., 2001).

Besides grazing, excessive shading is the next problem for the successful growth yew regeneration (Iszkuło \& Boratyński 2006; Dhar et al., 2008, Perrin \& Mitchell, 2013; Devaney et al., 2015). In natural populations, a large number of seedlings are observed to die in a short time after germination (Hulme, 1996; Svenning \& Magård, 1999; Thomas \& Polwart, 2003). One of the most important reasons is the insufficient light intensity at the forest floor (Niemczyk et al., 2015; Dhar et al., 2007). Therefore, there is a need to reduce excessive shading to actively promote the growth of natural regeneration. The reaction of yew saplings to changes of light conditions (e.g. by the reduction of canopy in natural populations) has not been analysed in detail yet. Nevertheless, the current results confirm the negative influence of full light exposure on growth and development of yew regeneration (Perrin \& Mitchell, 2013; Iszkuło et al., 2014).

In general, light significantly affects survival, growth and development of plants, which reflects in their adaptation to light conditions. Leaves morphology is particularly sensitive to light intensity. The needles in shady conditions are longer, have larger surface and specific leaf area (Wyka et al., 2008; Devaney et al., 2015). However, Devaney et al. (2015) found that the height of T. baccata individuals is much more important for needle morphology of saplings than light intensity. The main objective of this paper is to evaluate growth and recovery of T. baccata saplings after elimination of herbivory and the interaction between growth recovery and light intensity.

We tested the following hypotheses: (i) previous herbivory pressure has a negative influence on the growth rate and needle morphology of Taxus baccata, (ii) initial and current light conditions affect the further growth and development of yew saplings, (iii) needle morphology is more correlated with sapling height than with light intensity.

\section{Material and methods}

\section{Study site}

The studied population of Taxus baccata is located in a mixed forest with dominant protective function in the Babki Forest District, Poland (geographic coordinates: N 52 ${ }^{\circ} 16^{\prime} 43^{\prime \prime}, \mathrm{E} 17^{\circ} 04^{\prime} 23^{\prime \prime}, 95 \mathrm{~m}$ a.s.1.). The area has an average annual precipitation of $544 \mathrm{~mm}$ and an 
average annual temperature of $8.3^{\circ} \mathrm{C}$, measured at the Kórnik meteorological station located four kilometres from study site (Cedro \& Iszkuło, 2011). The soil type is brown earth soil with sandy loam. In the experimental area, the forest stand is dominated by larch (Larix decidua Mill.) and oak (Quercus robur L.) and forms two canopy layers. The upper layer represents larch, the lower layer represents oak. Larch density is 86 trees per hectare, with mean height of $35.6 \mathrm{~m}$ ( \pm $0.393 \mathrm{SE})$ and mean diameter of $53.6 \mathrm{~cm}( \pm 1.87 \mathrm{SE})$. Oak density is 199 trees per hectare, with mean height of $26.4 \mathrm{~m}( \pm 0.298 \mathrm{SE})$ and mean diameter of 26.1 $\mathrm{cm}( \pm 0.554 \mathrm{SE})$ (for details, see Iszkuło et al., 2014).

\section{Establishment of study plots}

The population of Taxus baccata was established from the artificial regeneration. The history of seed and seedling treatments in the experiment is presented in Table 1. Prior to planting in the forest, the seedlings of $T$. baccata were grown in an artificially shaded outdoor garden in Kórnik under four different light rates of $2 \%, 8 \%, 30 \%$ and $100 \%$ of full solar radiation ("initial light variant", Iszkuło et al., 2014). In 2006, four-year-old saplings were planted in a $3 \times 3 \mathrm{~m}$ spacing at three sample plots (blocks of $24 \times 24 \mathrm{~m}$ ), each divided into fenced and unfenced part ("treatment"). We used 16 saplings from each initial light variant resulting in a total of 384 analysed saplings (16 saplings $\times 4$ initial light variants $\times 2$ treatments $\times 3$ blocks). From 2006 to 2011, all unfenced yew saplings were intensively grazed (see Iszkuło et al., 2014, for details). In 2011, the mean ( \pm standard error) height of grazed saplings was $27.23 \mathrm{~cm}( \pm 1.65)$, and the mean height of un-grazed saplings was 71.47 $\mathrm{cm}( \pm 2.88)$. The highest mortality was noted in the first year of planting (2006) and for the particular light variants in fenced treatment it reached $46 \%$ ( $2 \%$ of full sunlight), $33 \%$ ( $8 \%$ of full sunlight), $6 \%$ (30\% of full sunlight) and $0 \%$ (full sunlight), with the overall average of $21 \%$. In the unfenced variant, the respective mortality rates were $58 \%, 29 \%, 15 \%$ and $8 \%$, with the overall average of $27 \%$. The mortality

Table 1. History of Taxus baccata seed and seedling treatments in the experiment

\begin{tabular}{lc}
\hline \multicolumn{1}{c}{ Treatments } & Year \\
\hline $\begin{array}{l}\text { Collecting seeds from } 10 \text { parent individuals in the } \\
\text { Malinówka (SE Poland) nature reserve }\end{array}$ & 2000 \\
Seed stratification and storage (according to Suszka & \\
1985) & 2000-2002 \\
Growth in the nursery in the Kórnik Arboretum & 2002-2003 \\
Growth in artificial shading at 2, 8, 30 and 100\% & 2003-2006 \\
full sunlight & \\
$\begin{array}{l}\text { Growth in the forest in fenced and unfenced plots } \\
\text { (see Iszkuło et al. 2014) }\end{array}$ & 2006-2011 \\
Growth in the forest only in fenced plots (fencing & 2011-2016 \\
unfenced plots - this study) &
\end{tabular}

by 2011 was lower in the fenced treatment $(35 \%$ in total) than in the unfenced treatment ( $45 \%$ in total) (see Iszkuło et al., 2014 for details).

\section{Measurement of parameters}

At the end of growing season in 2011, all plots without protection against herbivory were fenced in order to eliminate the herbivory damage. In June 2016, we measured the actual height of every T. baccata sapling and the five annual height increments of growing seasons 2011-2015 to an accuracy of $1 \mathrm{~cm}$ at the bud whorls along the main (highest) axis of the sapling (Fig. 2). Simultaneously to height measurements, we evaluated the survival and recovery of all Taxus baccata saplings. For each sapling, we counted the number of produced stems higher than half of the height of the particular sapling. In addition to the vertical growth of saplings, the horizontal growth was recorded by measuring crown diameter in two perpendicular directions. In the analysis, we used the mean crown diameter.

In addition, we measured the length of the lateral increment in order to calculate the light factor (Honowski light factor), presenting the ratio of the length of the longest side shoot and the terminal shoot in the particular year. Honowski light factor describes the relationship between light of actual forest stand and current growth of yew saplings. Light factor was used to describe the crown morphology and habit of saplings, which is indirect indicator of light conditions in the understorey. A value below 1.2 indicates a large increase of the terminal shoot, often resulting in a well-formed crown and a healthy young tree. In contrast, a value above 2.0 indicates a reduction in tree height and thus a rather limited suppressed tree (Kupferschmid et al., 2013, Fabijanowski et al. 1974).

Light intensity (PPFD) was measured by a quantum light sensor (Spectrum Inc.) in June 2016 at the time of full foliage of the canopy layer. It was important to observe the principles of measurement under

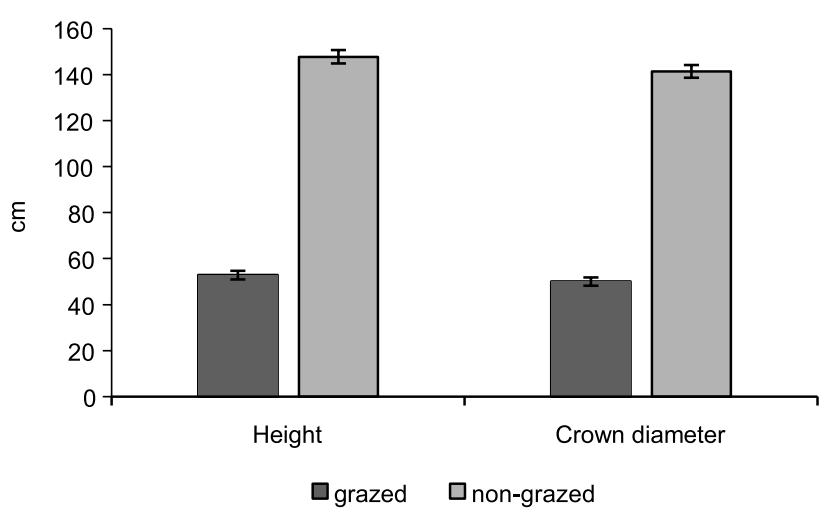

Fig. 1 Means of height and crown diameter ( \pm standard error) of grazed and non-grazed Taxus saplings 


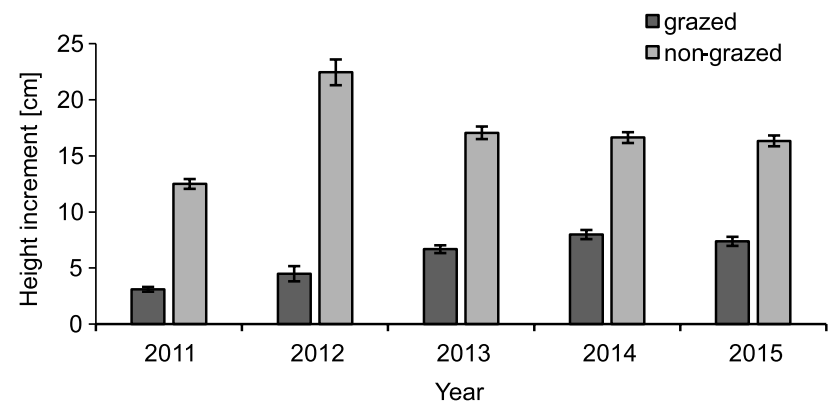

Fig. 2 Mean value ( \pm standard error) of height increment in 2011-2015 of non-grazed and previously grazed saplings of $T$. baccata

standard overcast conditions (cloudy day), to ensure reliable data of relative radiation. Two measurements were recorded in perpendicular directions at the height of each yew sapling and the mean value was considered as a characteristic of the light conditions at this stand. At the time of PPFD measurement, light in an open area with the use of a light sensor was recorded. Relative PPFD (RPPFD) was calculated as the ratio of mean PPFD in the plots in the forest to the PPFD in the open area at the same time.

For the analysis of yew needle morphology, we used 20 needles from whorl formed in growing season 2015. Needles were collected from a south-oriented lateral shoot. The needle samples were chosen to cover all types of initial light $(2,8,30$ a $100 \%$ of RPPFD) and include the widest possible range of the light condition in the forest. In total, there were 48 samples, specifically 2 treatments $\times 4$ types of initial light $\times 6$ light classes in the forest stand (class to 5 , $5-7,7-9,9-11,11-13$, above $13 \%$ of RPPFD) $=48$ samples. Fresh needles were measured and analysed using WinSeedle (Regent Instrument Inc.). From the WinSeedle output file we used means of needle length $(\mathrm{mm})$, needle width $(\mathrm{mm})$ and needle area $\left(\mathrm{mm}^{2}\right)$. For analysis of morphological parameters, we used the mean values of these 20 needles. Subsequently, the needles were dried at $60^{\circ} \mathrm{C}$ for 3 days and weighed to calculate specific leaf area (SLA), which is the ratio of total projection area to dry mass.

\section{Data analysis}

The multivariate approach (MANOVA, O'Brien \& Kaiser 1985) to repeated measures was used to analyse the yearly increment of saplings. Percent data (light intensity) were transformed with an arcsine function, which normalised distributions in order to satisfy the assumptions of MANOVA. Between MANOVA subjects, the T-test was used. Within MANOVA subjects, T-test, Wilks' Lambda, Pillai's Trace and Hotelling-Lawley Trace were also examined and allowed consistent interpretations in all cases. Mixed model analysis of covariance (ANCOVA) was used to compare grazing, RPPFD (as a covariant) and height, crown diameter, needle area, length, width, SLA, and Honowski light factor of T. baccata saplings. Statistical model included: 1) random variables: block, block nested in grazing and 2) constant variables: grazing, relative variations. All data were analysed using JMP Pro 12.0 (SAS Institute Inc.).

\section{Results}

The total number of Taxus baccata saplings in 2016 was 341 , which represents around $0 \%$ of mortality, compared with year 2011 (342 saplings).

Light intensity in experimental plots varied approximately between 3 and 16\% of RPPFD, with a mean value of $8.24 \%$ of RPPFD ( \pm 0.099 SE). Extreme values of light intensity fluctuated between particular plots, but the differences between plots were not significant (ANOVA, $\mathrm{F}=1.653 \mathrm{P}=0.1453, \mathrm{~N}=64$ samples per plot $=384$ per experiment.). Preliminary analysis found that initial light level had no significant effects and thus this variable is not considered further.

\section{Growth parameters}

There was a significant influence of grazing on height and crown parameters (Fig. 1), but the influence of RPPFD was not significant (Table 2). The non-grazed saplings reached the mean height 147.77 $\mathrm{cm}( \pm 2.912 \mathrm{SE})$ and grazed saplings $52.81 \mathrm{~cm}( \pm$ $1.880 \mathrm{SE})$. Non-grazed saplings had also larger dimension of crown with the mean crown diameter of $141.40 \mathrm{~cm}( \pm 2.768 \mathrm{SE})$ in contrast with grazed saplings with the mean value $50.0 \mathrm{~cm}( \pm 1.803 \mathrm{SE})$.

There was no significant influence of RPPFD on height increment of yew saplings (Table 3). The growth rate of $T$. baccata saplings was mainly influenced by grazing and changed over time (Table 3). Saplings had higher height increments in the fenced subplots. Mean height increment during the period 2011-2015 for grazed T. baccata saplings was $5.92 \mathrm{~cm}$ ( $\pm 0.266 \mathrm{SE}$ ), while non-grazed saplings showed an increment of $16.92 \mathrm{~cm}$ per year $( \pm 0.379 \mathrm{SE})$. Until 2014 there was a general trend for the height increments of grazed saplings to increase over time (Fig. 2). However, the height increment in 2015 was similar to that in 2014, which indicates equal growth

Table 2. Mixed model analysis of covariance (ANCOVA) used to compare grazing, RPPFD (as a covariant) and height, crown diameter of $T$. baccata saplings

\begin{tabular}{ccccc}
\hline \multicolumn{1}{c}{ Feature } & Variables & DF & F Ratio & P \\
\hline Height & Grazing & 1 & 744.71 & $<.0001$ \\
& RPPFD & 1 & 0.0201 & 0.8875 \\
Crown diameter & Grazing & 1 & $734 . .34$ & $<.0001$ \\
& RPPFD & 1 & 0.0039 & 0.9501 \\
\hline
\end{tabular}


Table 3. Repeated Measures Analysis of T. baccata yearly increment (years 2011-2015) against time effect and grazing, with RPPFD as a covariant

\begin{tabular}{lllc}
\hline \multicolumn{1}{c}{ Variables } & F Value & DF & Prob $>$ F \\
\hline \multicolumn{4}{l}{ Between subjects } \\
\hline Grazing & 1.3330 & 1 & $<0.0001$ \\
RPPFD & 0.0039 & 1 & 0.2506 \\
\hline \multicolumn{4}{l}{ Within subjects } \\
\hline Time & 0.1101 & 4 & $<0.0001$ \\
Time $\times$ Grazing & 0.1891 & 4 & $<0.0001$ \\
Time $\times$ RPPFD & 0.0232 & 4 & 0.1032 \\
\hline
\end{tabular}

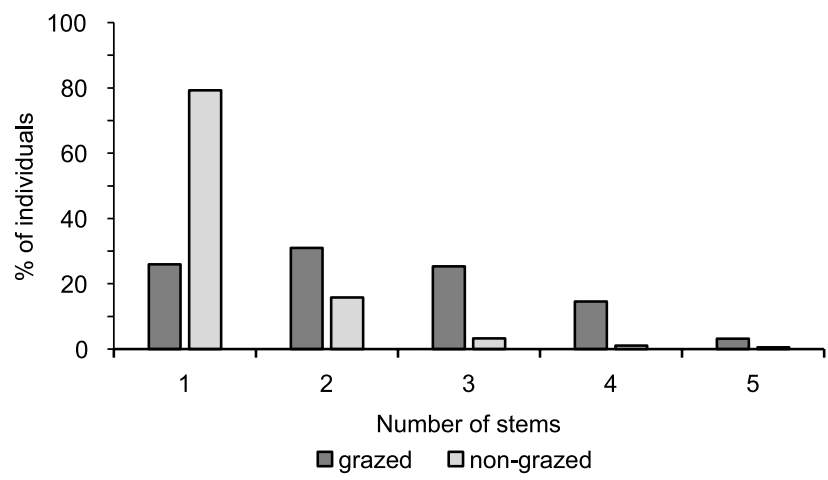

Fig. 3 Differences between number of saplings forming side shoots in grazed and non-grazed T. baccata saplings

in previously grazed saplings (Fig. 2). Contrary to the height increment, sapling habitus expressed by Honowski light factor was not influenced neither by grazing nor by RPPFD.

In addition, the herbivory pressure on young yew saplings became evident by the formation of polycormic (multi-stemmed) individuals. The occurrence of one main stem was dominant in non-grazed saplings $(79.23 \%)$ but not in grazed saplings $(25.94 \%)$, which tended to polycormicy as a reaction to grazing (Fig. 3).

\section{Needle morphology}

Grazing history had significant influence on the morphology of $T$. baccata needles, while RPPFD had not significant effect on any of the analysed parameters

Table 4. Mixed model analysis of covariance (ANCOVA) used to compare grazing, RPPFD (as a covariant) and needle area, length, width, SLA, and Honowski light factor of $T$. baccata saplings

\begin{tabular}{llcrc}
\hline & Source & DF & F Ratio & P \\
\hline Area & Grazing & 1 & 40.626 & 0.0230 \\
& RPPFD & 1 & 1.1592 & 0.2881 \\
Length & Grazing & 1 & 64.1953 & 0.0124 \\
& RPPFD & 1 & 1.1994 & 0.2805 \\
\multirow{3}{*}{ Sidth } & Grazing & 1 & 0.2459 & 0.6690 \\
& RPPFD & 1 & 1.4562 & 0.2342 \\
\multirow{3}{*}{ Light factor } & Grazing & 1 & 28.4606 & 0.0370 \\
& RPPFD & 1 & 0.0309 & 0.8613 \\
& Grazing & 1 & 0.0809 & 0.8033 \\
& RPPFD & 1 & 0.0121 & 0.9129 \\
\hline
\end{tabular}
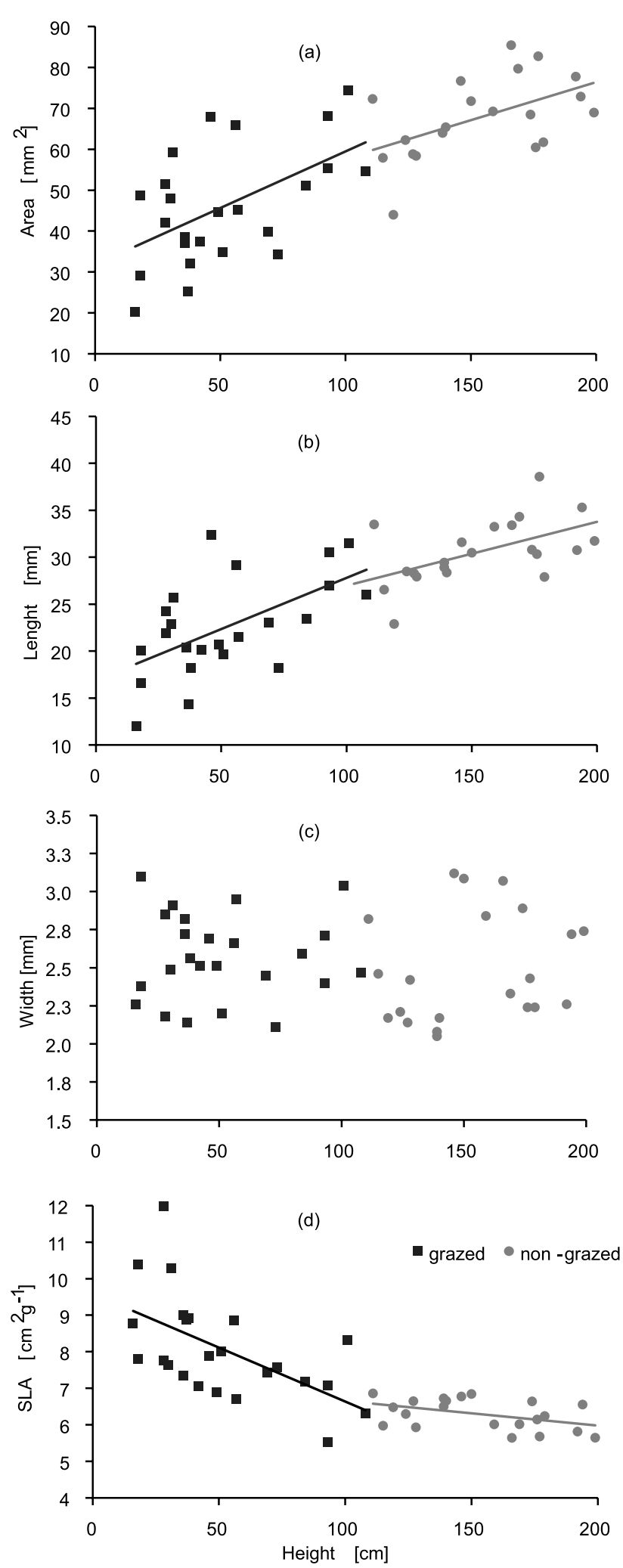

Fig. 4 Relationship between height of $T$. baccata saplings and needle area: (a) grazed: $\mathrm{R}^{2}=0.287, \mathrm{p}=0.007$, nongrazed: $\mathrm{R}^{2}=0.275 \mathrm{p}=0.0148$, length $(\mathrm{b})$ grazed: $\mathrm{R}^{2}=$ $0.337, p=0.0029$, non-grazed $R^{2}=0.2978 p=0.0105$, width (c) grazed: $R^{2}=0.0001, p=0.8972$, non-grazed: $\mathrm{R}^{2}=0.0425, \mathrm{p}=0.3701$, SLA $(\mathrm{d})$ grazed: $\mathrm{R}^{2}=0.331, \mathrm{p}$ $=0,0033$, non-grazed $R^{2}=0.199 p=0.0429$ 
Table 5. Mean ( \pm standard error) values of SLA, Honowski light factor, needle area, length and width of T. baccata saplings

\begin{tabular}{lccccc}
\hline & SLA $\left(\mathrm{cm}^{2} \mathrm{~g}^{-1}\right)$ & Light factor $\left(\mathrm{cm} \mathrm{cm}^{-1}\right)$ & Area $\left(\mathrm{mm}^{2}\right)$ & Length $(\mathrm{mm})$ & Width $(\mathrm{mm})$ \\
\hline Grazed & $8.07 \pm 0.289$ & $2.16 \pm 0.322$ & $46.09 \pm 2.906$ & $22.51 \pm 1.057$ & $2.57 \pm 0.058$ \\
Non-grazed & $6.56 \pm 0.198$ & $2.01 \pm 0.671$ & $63.41 \pm 2.663$ & $29.41 \pm 0.936$ & $2.48 \pm 0.070$ \\
\hline
\end{tabular}

(Table 4). Non-grazed needles had a greater projection area, length and lower SLA compared to needles from grazed Taxus saplings (Table 5).

The height of $T$. baccata saplings was positively correlated with needle area and length (Figs. 4a, b) and negatively correlated with SLA (Fig. 4d). Needle width was not correlated with sapling height (Fig. $4 c)$.

\section{Discussion}

Our investigations have shown that previous grazing (six years) was the most important factor affecting the growth rate and morphology of yew needles. Our results therefore confirmed the first hypothesis that herbivory pressure has a significant negative influence on growth of yew juveniles and parameters of needle morphology. Contrary to grazing, light conditions in the analysed plots had no significant influence on further growth and development of yew saplings.

\section{Grazing}

\section{Mortality}

Despite the previous heavy herbivory damage on plots unfenced until 2011 (Iszkuło et al., 2014), there was negligible mortality of yew juveniles in the monitored growing seasons. Grazing is a significant cause of mortality of youngest seedlings, however, with increasing age, the negative influence of grazing diminishes (Harmer, 2001). Most deciduous tree species of temperate zones are able to survive long-lasting herbivory attacks if they survive the first critical vegetative season (Ammer et al., 2010). Conifers usually have higher mortality rates in the subsequent growing years because of their poorer regeneration abilities. Taxus baccata, growing on favourable sites, has high regeneration abilities, which makes it an exception among conifers (Thomas \& Polwart, 2003). However, its dioiceous character makes it vulnerable in forest stands with varied climatic conditions (Garbarino et al., 2015; Vessella et al., 2015).

\section{Growth}

Height growth of yew saplings was significantly affected by previous grazing, and saplings damaged by herbivores had more than three times lower height and more than twice slower height increment values in the fourth and fifth year after fencing than saplings protected from herbivory. Browsing frequently damages the most palatable parts of saplings, i.e. leading shoots, buds and upper leaves that are the most actively growing and nutritious parts, thereby physically reducing juvenile height (Gill \& Beardall, 2001; Bergquist et al., 2003). It should be noted that increases in height growth of grazed saplings were observed for the first four years, but in the fifth year after eliminating grazing pressure, tree growth was similar (Fig. 2). Stagnation of height growth is generally the most frequent evident consequence of intensive herbivory in young forest stands (Harmer, 2001; Ammer et al., 2010). Due to the influence of height increment on the current height of individuals (Uzoh \& Oliver, 2008), we recorded lower absolute values of height increment for previously grazed (lower) yew saplings than for non-grazed saplings. Even after four vegetative seasons without herbivory damage, the previously grazed saplings did not reach the mean yearly height increment of the non-grazed ones. This indicates that browsed saplings suffer an impairment in height growth and are not able to catch up with non-browsed ones. There are three main mechanisms to reduce the impacts of herbivory: escape, defence or tolerance (Boege \& Marquis, 2005). In our study, limited height and reduced leaf area of grazed saplings might be a measure of escape or avoidance, resulting in a reduced likelihood to be grazed by herbivores or decreased attractiveness (Milchunas \& Noy-Meir, 2002). Another response of grazed Taxus baccata juveniles was the formation of more than one stems. Once the damage has occurred, the negative impacts of herbivory can be reduced through tolerance, which means the ability of recovery and maintaining a healthy condition (Boege \& Marquis, 2005). The production of higher number of shoots or sprouts is a mechanism by which some conifers may react and recover after disturbance in the sapling stage (Del Tredici, 2001). Most of grazed T. baccata saplings (74\%) in the studied area had more than one stem, in comparison, nearly $80 \%$ of un-grazed trees monocormic (Fig. 3). In a similar study, previous herbivory damage had a considerable impact on Sitka spruce (Picea sitchensis) sapling morphology, because damaged spruces had significantly lower height, tree span, and leader shoot width and length compared to undamaged trees (Duncan et al., 1998). Wallgren et al. (2014) found that grazing may require Scots pines (Pinus sylvestris) to allocate more resources into the compensation of the removed tissues, such as forming new buds, and less into height and diameter growth. Similar results has been found by Rasmussen et al. (2003) in case of growth allocation changes of Abies nordmanniana $\mathrm{L}$. 
European yew develops lateral buds at irregular intervals, they are frequent along the stem, which explains why T. baccata can withstand pruning the main trunk (Thomas \& Polwart, 2003). In addition, Taxus baccata has a tendency to form multiple stems (Thomas \& Polwart, 2003), but it seems that in undisturbed populations, most individuals are monocormic, this was the case in the Knyazhdvir Nature Reserve (Ukraine), where the percentage of one-stemmed individuals ranged between 74 and $87 \%$ (Iszkuło et al., 2005), similar to the percentage of one-stemmed, un-grazed saplings in our study.

\section{Needle morphology}

Grazing had also a negative impact on the needle morphology of studied yews. The non-grazed yew saplings had a greater surface area and needle length than the grazed yew saplings. According to Kartusch \& Richter (1984), the morphological changes of $T$. baccata needles are probably the result of water transport impairment to the tree body through the cutting of the stems, because stem cutting causes a form of xeromorphic needles with reduced leaf area, a thicker cuticule and smaller inner cells. This might characterise an escape mechanism from grazing, in particular due to the small leaf size and the high leaf dry matter content, however, in our study, the SLA of juvenile yew needles increased under herbivore pressure and was higher in grazed than in non-grazed saplings. This finding is in agreement which the observation of other authors who confirmed that grazing tolerance can be expressed as high specific leaf area (SLA) and low leaf toughness, which increase shoot regrowth ability and selectivity by herbivores (Zheng et al., 2010).

\section{Light intensity}

\section{Growth}

We found no effect of light conditions on T. baccata growth rates, confirming earlier findings by Iszkuło (2014) who transferred saplings from different to similar light conditions. Mean light intensity dropped from 13.95\% ( $\pm 0.1807 \mathrm{SE}$ ) in 2011 (Iszkuło et al., 2014) to $8.24 \%$ ( $\pm 0.099 \mathrm{SE}$ ) in 2016 , but still there was no significant influence of light on yew growth, although light demand increases with increasing age (Iszkuło \& Boratyński, 2006). According to Iszkuło \& Boratyński (2006), the ecological light optimum of Taxus baccata is $2-7 \%$ of full sun, but the physiological light optimum is much higher (Iszkuło, 2010). Forest ecosystems with natural occurrence of T. baccata in Europe are often beech-dominated (Linares 2013), as a consequence, they have a low light intensity in the understorey. However, the results under controlled light conditions $(2,8,30$ and $100 \%$ of full sun) indicated optimum growth at 8 and $30 \%$ of full sun (Iszkuło, 2010). In our studied forest stand, relative radiation ranges between 3 and 16\% of RPPFD, which can be a small range for the observation of growth reactions to light. Height growth of Taxus was significantly influenced by light environment in several studies (Iszkuło 2010; Perrin \& Mitchell, 2013; Devaney et al., 2015; Peragón et al., 2015), however, these works have been performed in broader intervals of light intensity. Additionally, yew juveniles grow under light-demanding tree species (oak, larch) that lose their leaves each year. The general statement is that shade-tolerant and evergreen species begin to grow very early in spring, before the deciduous tree species leaf out, and finish their growth after the defoliation of the deciduous trees (Gill et al., 1998; Walters \& Reich, 1999). Average annual height increases in the years 2011-2015 in non-grazed saplings was about $17 \mathrm{~cm}$. In other studies, mean height growth rates were much lower (Perrin \& Mitchell, 2013; Niemczyk et al., 2015; Peragón et al., 2015). This indicates that the light conditions in the experiment were sufficient for optimum growth. All analysed Taxus juveniles had values of the Honowski light factor higher than 2, suggesting a flat, wide and umbrella-shaped crown, which is an indicator of suppressed saplings in the understorey (Kupferschmid et al., 2013). Williams et al. (1999) confirmed that the tendency of tree crowns to horizontal growth is mainly a result of low light conditions and a characteristic feature of shade-tolerant species. Horizontal growth at the expense of height growth may explain the ability to survive for many years under shaded conditions (Messier et al., 1999).

\section{Needle morphology}

As in the case of growth, there was no effect of RPPFD on needle morphology. This finding is surprising because these calculated leaf traits are common predictors of light intensity (Fabjanowski et al., 1974; Zheng et al., 2010), our results therefore indicate that these methods are not suitable to evaluate light conditions of $T$. baccata stands in small a range of light intensity (between 3 and $16 \%$ of full sunlight). Another reason for the lack of correlation could be the distribution of sample points within this range and also the sampling method and sample size.

However, the needle length and area were positively and SLA negatively correlated with yew height (Fig.4). These results correspond with the findings of other studies in conifers (e.g. Steele et al., 1989; Lilles et al., 2014). Greater needle size in higher plants is often explained with a transition from shade to sun leaves (Steele et al., 1989) or preparation for reproduction (Thomas, 2011). Indeed, we could not observe sexual determinants of saplings in yew individuals in the analysed plots. 


\section{Conclusions}

Herbivory pressure has a negative effect on the growth and needle morphology of Taxus juveniles. Six years of grazing influenced height growth, needle parameters and number of stems, and these impacts markedly affected the development in the subsequent five years, irrespective of herbivory elimination. Height reduction, polycormicy, and needle size reduction indicate a persisting species strategy as a result of escaping from grazing. The effect of light conditions in the range of $3-16 \%$ on needle morphology was not significant. A good growth of non-grazed T. baccata saplings in the experiment shows appropriate light conditions ranging from 3 to $16 \%$ of full light. We also confirmed the correlation between needle size and individual sapling height.

\section{Acknowledgments}

This study was supported by the Institute of Dendrology, Polish Academy of Sciences, Kórnik, Poland, University of Zielona Gora, and by the Slovak Research and Development Agency, project under the grant No. APVV-14-0014. We would like to thank Marian Giertych and Radosław Jagiełło for help in statistical analyses, the Babki Forest District (Polish State Forests), K. M. acknowledges the receipt of Erasmus Plus placement scholarships from the EU and her home university, Technical University in Zvolen, Slovakia.

\section{References}

Ammer C, Vor T, Knoke T \& Wagner S (2010) Der wald-wild-konflikt. Analyse und lösungsansätze vor dem hintergrund rechtlicher, ökologischer und ökonomisher zusammenhänge. University of Göttingen, Germany.

Augustine DJ \& McNaughton SJ (1998) Ungulate effects on the functional species composition of plant communities: herbivore selectivity and plant tolerance. The Journal of Wildlife Management 62: 1165-1183.

Bergquist J, Örlander G \& Nilsson U (2003) Interactions among forestry regeneration treatments, plant vigour and browsing damage by deer. New Forests 25: 25-40. doi:10.1023/A:1022378908827.

Boege K \& Marquis RJ (2005) Facing herbivory as you grow up: The ontogeny of resistance in plants. Trends In Ecology \& Evolution 20: 441448. doi:10.1016/j.tree.2005.05.001.

Del Tredici P (2001) Sprouting in temperate trees: A morphological and ecological review. The Botanical Review 67: 121-140. doi:10.1007/ BF02858075.
Devaney JL, Whelan PM \& Jansen MAK (2015) Light responses of yew (Taxus baccata L.); does size matter? Trees 29: 109-118. doi:10.1007/s00468-0141095-x.

Dhar A, Ruprecht H, Klumpp R \& Vacik H (2007) Comparison of ecological condition and conservation status of English yew population in two Austrian gene conservation forests. Journal of Forestry Research 18: 181-186.

Dhar A, Ruprecht H \& Vacik H (2008) Population viability risk management (PVRM) for in situ management of endangered tree species-A case study on a Taxus baccata L. population. Forest Ecology and Management 255: 2835-2845.

Duncan AJ, Hartley SE \& Iason GR (1998) The effect of previous browsing damage on the morphology and chemical composition of Sitka spruce (Picea sitchensis) saplings and on their subsequent susceptibility to browsing by red deer (Cervus elaphus). Forest Ecology and Management 103: 5767. doi:10.1016/S0378-1127(97)00177-1.

Fabjanowski J, Jaworski A \& Musiel W (1974) The use of certain morphological features of the fir (Abies alba Mill.) and spruce (Picea abies Link.) in the evaluation of the light requirements and quality of their up-growth (Orig. Poln.). Acta Agraria et Silvestris, Series Silvestris 14: 3-29.

Farris E, Fenu G \& Bacchetta G (2012) Mediterranean Taxus baccata woodlands in Sardinia: A characterization of the EU priority habitat 9580 . Phytocoenologia 41: 231-246. doi:10.1127/0340269X/2011/0041-0501

Farris E \& Filigheddu R (2008) Effects of browsing in relation to vegetation cover on common yew (Taxus baccata L.) recruitment in Mediterranean environments. Plant Ecology 199: 309-318.

Garbarino M, Weisberg PJ, Bagnara L \& Urbinati C (2015) Sex-related spatial segregation along environmental gradients in the dioecious conifer, Taxus baccata. Forest Ecology and Management 358: 122-129. doi:10.1016/j.foreco.2015.09.009.

García D, Zamora R, Hódar JA, Goméz JM \& Castro J (2000) Yew (Taxus baccata L.) regeneration is facilitated by fleshy-fruited shrubs in Mediterranean environments. Biological Conservation 95: 31-38. doi:10.1016/S0006-3207(00)00016-1.

Gill DS, Amthor JS \& Bormann FH (1998) Leaf phenology, photosynthesis, and the persistence of saplings and shrubs in a mature northern hardwood forest. Tree Physiology 18: 281-289. doi:10.1093/treephys/18.5.281.

Gill RMA \& Beardall V (2001) The impact of deer on woodlands: The effects of browsing and seed dispersal on vegetation structure and composition. Forestry 74: 209-218. doi:10.1093/forestry/74.3.209. 
Harmer R (2001) The effect of plant competition and simulated summer browsing by deer on tree regeneration. Journal of Applied Ecology 38: 10941103. doi: $10.1046 / j .1365-2664.2001 .00664 . x$.

Heuze P, Schnitzler A \& Klein F (2005) Consequences of increased deer browsing winter on silver fir and spruce regeneration in the Southern Vosges mountains: Implications for forest management. Annals of Forest Science 62: 175-181. doi:10.1051/forest:2005009.

Hulme PE (1996) Natural regeneration of yew (Taxus baccata L.): microsite, seed or herbivore limitation? Journal of Ecology 84: 853-861.

Iszkuło G (2010) Success and failure of endangered tree species: Low tepmeratures and low light availability affect survival and growth of European yew (Taxus baccata L.) seedlings. Polish Journal of Ecology 58: 259-271.

Iszkuło G \& Boratyński A (2006) Analysis of the relationship between photosynthetic photon flux density and natural Taxus baccata seedlings occurrence. Acta Oecologica 29: 78-84. doi:10.1016/j. actao.2005.08.001.

Iszkuło G, Boratyński A, Didukh Y, Romaschenko K \& Pryazhko N (2005) Changes of population structure of Taxus baccata L. during 25 years in protected area (Carpathians, Western Ukraine). Polish Journal of Ecology 53: 13-23.

Iszkuło G, Nowak-Dyjeta K \& Sekiewicz M (2014) Influence of initial light intensity and deer browsing on Taxus baccata saplings: A six years field study. Dendrobiology 71: 93-99. doi:10.12657/ denbio.071.009.

Kamler J, Homolka M, Barančeková M \& Krojerová-Prokešová J (2010) Reduction of herbivore density as a tool for reduction of herbivore browsing on palatable tree species. European Journal of Forest Research 129: 155-162. doi:10.1007/ s10342-009-0309-z.

Kartusch B \& Richter H (1984) Anatomische Reaktionen von eibennadeln auf eine erschwerung des wassertransports im pflanzenkörper. Phyton (Austria) 24: 295-303.

Katsavou I \& Ganatsas P (2012) Ecology and conservation status of Taxus baccata population in NE Chalkidiki, northern Greece. Dendrobiology 68: 55-62.

Kupferschmid AD, Zimmermann S \& Bugmann H (2013) Browsing regime and growth response of naturally regenerated Abies alba saplings along light gradients. Forest Ecology and Management 310: 393-404. doi:10.1016/j.foreco.2013.08.048.

Lilles EB, Astrup R, Lefrancois ML \& Coates KD (2014) Sapling leaf trait responses to light, tree height and soil nutrients for three conifer species of contrasting shade tolerance. Tree Physiology 34: 1334-1347. doi:10.1093/treephys/tpu092.
Magnuszewski M (2015) Programme of restitution Taxus baccata L . and Sorbus torminalis (L.) Crantz in Polish State Forests: Ex situ conservation of plants - problems and solutions. Conference 9-13 September 2015, Poznań, Poland. https://www. researchgate.net/publication/282317594_Programme_of_restitution_Taxus_baccata_L_and_ Sorbus_torminalis_L_Crantz_in_Polish_State_ Forests.

Messier C, Doucet R, Ruel JC, Claveau Y, Kelly C \& Lechowicz MJ (1999) Functional ecology of advance regeneration in relation to light in boreal forests. Canadian Journal of Forest Research 29: 812-823. doi:10.1139/x99-070.

Milchunas DG \& Noy-Meir I (2002) Grazing refuges, external avoidance of herbivory and plant diversity. Oikos 99: 113-130. doi:10.1034/j.16000706.2002.990112.x.

Mysterud A \& Østbye E (2004) Roe deer (Capreolus capreolus) browsing pressure affects yew (Taxus baccata) recruitment within nature reserves in Norway. Biological Conservation 120: 545-548. doi:10.1016/j.biocon.2004.03.027.

Niemczyk M, Żółciak A \& Wrzesiński P (2015) The influence of stand canopy openness on the growth of common yew (Taxus baccata L.). Forest Research Papers 76: 42-48. doi:10.1515/frp-2015-0004.

Peragón JLN, Matías LFB \& Simón JP (2015) Restoration of European yew (Taxus baccata L.) in Mediterranean mountains: importance of seedling nursery fertilization and post-planting light levels. Forest Systems 24: e041. doi:10.5424/ fs/2015243-07464.

Perrin PM \& Mitchell FJG (2013) Effects of shade on growth, biomass allocation and leaf morphology in European yew (Taxus baccata L.). European Journal of Forest Research 132: 211-218. doi:10.1007/s10342-012-0668-8.

Perrin PM, Kelly DL \& Mitchell FJG (2006) Longterm deer exclusion in yew-wood and oakwood habitats in southwest Ireland: Natural regeneration and stand dynamics. Forest Ecology and Management 236: 356-367. doi:10.1016/j.foreco.2006.09.025.

Rasmussen HN, Soerensen S \& Andersen L (2003) Bud set in Abies nordmanniana Spach. influenced by bud and branch manipulations. Trees - Structure and Function 17: 510-514. doi:10.1007/ s00468-003-0268-9.

Schirone B, Ferreira RC, Vessella F, Schirone A, Piredda R \& Simeone MC (2010) Taxus baccata in the Azores: A relict form at risk of imminent extinction. Biodiversity and Conservation 19: 15471565. doi:10.1007/s10531-010-9786-0.

Steele MJ, Coutts MP \& Yeoman MM (1989) Developmental changes in Sitka spruce as indices of 
physiological age, I. Changes in needle morphology. New Phytologist 113: 367-375.

Svenning JC \& Magård E (1999) Population ecology and conservation status of the last natural population of English yew Taxus baccata in Denmark. Biological Conservation 88: 173-182. doi:10.1016/ S0006-3207(98)00106-2.

Tanentzap AJ, Kirby KJ \& Goldberg E (2012) Slow responses of ecosystems to reductions in deer (Cervidae) populations and strategies for achieving recovery. Forest Ecology and Management 264: 159-166. doi:10.1016/j.foreco.2011.10.005.

Thomas PA \& Polwart A (2003) Taxus baccata L. Journal of Ecology 91: 489-524. doi:10.1046/j.13652745.2003.00783.x.

Thomas P \& Garcia-Marti X (2015) Response of European yews to climate change: a review. Forest Systems 24: eR01. doi: 10.5424/fs/201524307465.

Thomas SC (2011) Age-related changes in tree growth and functional biology: The role of reproduction: Size- and age-related changes in tree structure and function, Tree Physiology (ed. By FC Meinzer, B Lachenbruch \& TE Dawson) Springer, Netherland, pp. 33-64.

Uzoh FCC \& Oliver WW (2008) Individual tree diameter increment model for managed even-aged stands of ponderosa pine throughout the western United States using a multilevel linear mixed effects model. Forest Ecology and Management 256: 438-445. doi:10.1016/j.foreco.2008.04.046.

Vessella F, Salis A, Sciré M, Piovesa G \& Schirone B (2015) Natural regeneration and gender-specific spatial pattern of Taxus baccata in an old-growth population in Foresta Umbra (Italy). Dendrobiology 73: 75-90. doi:10.12657/denbio.073.008.

Vessella F, Simeone MC, Fernandes FM, Schirone A, Gomes MP \& Schirone B (2013) Morphological and molecular data from Madeira support the persistence of an ancient lineage of Taxus baccata L. in
Macaronesia and call for immediate conservation actions. Caryologia 66: 162-177. doi:10.1080/00 087114.2013.821842.

Vila B, Torre F, Guibal F \& Martin JL (2003) Growth change of young Picea sitchensis in response to deer browsing. Forest Ecology and Management 180: 413-424. doi:10.1016/S0378-1127(02)00655-2.

Wallgren M, Bergquist J, Bergström R \& Eriksson S (2014) Effects of timing, duration, and intensity of simulated browsing on Scots pine growth and stem quality. Scandinavian Journal of Forest Research 29: 734-746. doi:10.1080/02827581.2014 .960896.

Walters MB \& Reich PB (1999) Low-light carbon balance and shade tolerance in the seedlings of woody plants: do winter deciduous and broad-leaved evergreen species differ? New Phytologist 143: 143154. doi:10.1046/j.1469-8137.1999.00425.x.

Williams H, Messier C \& Kneeshaw DD (1999) Effects of light availability and sapling size on the growth and crown morphology of understory Douglas-fir and lodgepole pine. Canadian Journal of Forest Research 29: 222-231. doi:10.1139/cjfr29-2-222.

Wyka T, Robakowski P \& Zytkowiak R (2008) Leaf age as a factor in anatomical and physiological acclimative responses of Taxus baccata L. needles to contrasting irradiance environments. Photosynthesis Research 95: 87-99.

Zamora R, Gómez JM, Hódar JA, Castro J \& García D (2001) Effect of browsing by ungulates on sapling growth of Scots pine in a mediterranean environment: consequences for forest regeneration. Forest Ecology and Management 144: 33-42. doi:10.1016/S0378-1127(00)00362-5.

Zheng SX, Ren HY, Lan ZC, Li WH, Wang KB \& Bai YF (2010) Effects of grazing on leaf traits and ecosystem functioning in Inner Mongolia grasslands: scaling from species to community. Biogeosciences 7: 1117-1132. doi:10.5194/bgd-6-9945-2009. 